\title{
The Influence of Reading Fondness Characters on Students' Attitudes in Science Subjects in Junior High Schools
}

\author{
Muhammad Sofyan Zain ${ }^{1 *}$, Astalini², Dwi Agus Kurniawan ${ }^{3}$ (iD \\ ${ }^{1,2,3}$ Pendidikan Fisika, Universitas Jambi, Muaro Jambi, Indonesia \\ *Corresponding author: sofyanzain467@gmail.com
}

\section{Abstrak}

Banyak siswa yang memiliki tingkat kesenangan membaca yang rendah. Hal ini akan berdampak pada hasil belajar IPA umum bagi siswa. Kegemaran membaca diketahui dapat meningkatkan ranah kognitif siswa, bagaimana dengan sikap siswa yaitu ranah afektif? Tujuan penelitian ini adalah untuk mengukur pengaruh kegemaran membaca terhadap sikap pada mata pelajaran IPA di SMP. Sekolah yang diteliti terdiri dari 1 sekolah swasta dan 2 sekolah negeri dengan jumlah sampel sebanyak 411 siswa. Teknik pengambilan sampel adalah cluster sampling. Metode penelitian yang digunakan adalah kuantitatif dengan analisis regresi linier sederhana dan analisis statistik deskriptif. Instrumen yang digunakan adalah angket yang valid dan reliabel untuk kegemaran membaca dan sikap terhadap sains. Hasil penelitian ini menunjukkan bahwa kegemaran membaca siswa berada pada kategori baik, sikap terhadap sains berada pada kategori baik. Penelitian ini menyiratkan bahwa kebiasaan membaca siswa berpengaruh positif terhadap sains.

Kata kunci: Gemar Membaca, Sikap, Ilmu Pengetahuan

\section{Abstract}

Many students have a low level of reading pleasure. This will have an impact on common science learning outcomes for students. Reading fondness has been known to improve students 'cognitive domains, what about students' attitudes, namely the affective domain? The purpose of this study was to measure the effect of reading fondness on attitudes in science subjects in junior high schools. The schools studied consisted of 1 private school and 2 public schools with a total sample of 411 students. The sampling technique was cluster sampling. The research method used is quantitative with simple linear regression analysis and descriptive statistical analysis. The instrument used was a valid and reliable questionnaire for reading fondness and attitudes towards science. The results of this study indicate that students' reading pleasure is in the good category, the attitude towards science is in the good category This research implies that students' reading habit has a positive influence on science.

Keywords: Reading Fondness, Attitudes, Sciences

\begin{tabular}{|c|c|c|}
\hline \multicolumn{2}{|l|}{ History: } & Publisher: Undiksha Press \\
\hline Received & : February 19, 2021 & Licensed: This work is licensed under \\
\hline Revised & : March 30, 2021 & a Creative Commons Attribution 3.0 License \\
\hline Accepted & : April 10, 2021 & (c) (1) (0) \\
\hline Published & : April 25, 2021 & ${ }_{\text {EY }}$ SA \\
\hline
\end{tabular}

\section{Introduction}

So far, reading is one of the characters proposed by the Ministry of Education and Culture as a character that must be implemented at every level of primary and secondary education in Indonesia (Christianti, 2013; Ika Febriandari, 2019; Lian et al., 2020). The application of character education in Indonesia is not without reason. Character education is aimed at building awareness and social control in students' souls, in addition to better perceptions, intelligence, emotions, social relationships, and morality (Munawwaroh, 2019; Rosyad, 2019). However, in its implementation, schools are more concerned with the intelligence of students. The family environment also pays less attention to character education for their children so that the application of character, one of which likes to read is less successful (Yoga Purandina \& Astra Winaya, 2020). With the lack of schools and family environments improving character education, namely the love of reading to their students, students do not have attitudes or views in the form of positive behavior towards science. 
Someone who has a good reading motivation means that he has a good reading or fondness for reading (Astuti \& Istiarini, 2020; Hochweber \& Vieluf, 2018). Reading ability is a measure of the capacity to understand, participate in society, develop potential and knowledge, and reflect on the text to achieve the goals to be achieved (Asna \& Mimi, 2016; Maryani, Ichsan, \& Khairunnisa, 2017). In the PISA assessment of skills measured in the literacy aspect, in 2018, Indonesia was in position 74 out of 79 countries (Hewi \& Shaleh, 2020). Other research findings also state that many children have a low interest in reading (Maufur \& Puadah, 2015; Warsihna, 2016). So it can be seen that reading ability which has a relationship with reading motivation in Indonesia is still not good. The low reading ability and motivation in the field of science also reflects the lack of interest in reading among students.

Reading is a basic skill that is carried out to understand and answer curiosity through the content of reading to gain knowledge (Agathi Dian, Kristiantari, \& Ganing, 2015; Tse, Choi, \& Tang, 2019). Reading activities that have been carried out so far cannot be separated from academic learning activities that are generally carried out in class. In order for learning activities to take place optimally, valid learning materials are prioritized (Anjani, Dantes, \& Artawan, 2019; Purwanto \& Rizki, 2015; Sriyanto, Leksono, \& Harwanto., 2019). However, reading activities carried out by junior high school students are still experiencing problems, because reading preferences in the academic field such as science books are still not good (Le et al., 2019; Puspita, 2019). Most students read more non-academic books such as novels because they are more fun (Darmayasa, Jampel, \& Simamora, 2018; Vuong et al., 2019). In addition, students have poor reading skills and study habits, so that their understanding of the contents of their readings is lacking (Memiş \& Kandemir, 2019). Understanding of the content of this reading holds crucial importance in students' attitudes, because if students have difficulty understanding the content of the material, students will have a negative attitude towards what is read.(Öztürk, Akkan, \& Kaplan, 2020; Puryadi, Rahayu, \& Sutrio, 2018). Someone who does not like to read can be caused by the incompatibility of the content of the learning material with his age and the effect of anxiety on reading (Faruq, 2019). So from the statement above, it can be seen that the reading fondness is a character that aims to improve students' abilities in learning. The love of reading will create a positive attitude for students.

Attitude is included in the affective domain in learning (Genc, Genc, \& Rasgele, 2018; Novitasari \& Wardani, 2020). The learning outcomes that students get are inseparable from how positive attitudes are towards science subjects (Aini, Rachmatullah, \& Ha, 2019; Meilani, Dantes, \& Tika, 2020). The importance of knowing the influence of the character of reading fondness on attitudes is so that a person can know and apply the character of fond of reading in educational activities, so that there is an increase in attitudes in a positive direction. A positive attitude towards science subjects is when students like science and a negative attitude is when they don't like science subjects(Toma, Greca, \& Orozco Gómez, 2019; Wahyuni, Muslim, \& Pamujo, 2019). Attitudes arise from internal and external aspects. The internal aspect is a psychological, emotional, moral, physical, and spiritual development that comes from within (Muhtar \& Dalyono, 2020). While external aspects come from outside the students, for example the learning environment. Based on research, students who have a positive attitude towards science will be happy and without external coercion to buy reading books related to science (Rabgay, 2018). This happy attitude is driven by the affective domain that students get when they like learning science. With a positive attitude towards the subject, students will try to involve themselves in learning (Asghar et al., 2018). If students have a negative attitude towards science, the success of science learning will be disrupted and reduce future scientists (Smith et al., 2020; Wan Yunus \& Mat Ali, 2018). 
One of the affective domains is attitude which plays an important role in science learning. To improve attitudes towards science, there are many variables that influence it (Wu et al., 2019). Research on attitudes towards science has previously been carried out by (Aini et al., 2019; Maison et al., 2020; Simsar, 2018; Radu Bogdan Toma \& Greca, 2018). Research on the effect of another variable on attitudes in science (DiMaggio, Sotoudeh, Goldberg, \& Shepherd, 2018; Lee \& Kim, 2018; Radu Bogdan Toma \& Greca, 2018). Research on attitudes towards science from previous studies has not touched how the influence of reading pleasure from the indicators that the researchers developed on students' attitudes towards science subjects. So, with limitations and the absence of research concerning the effect of reading fondness on students' attitudes towards science subjects, this research is an update from previous research. With this research, the expected benefit for readers, especially academic activists, is to be able to understand the influence of the character of liking to read on students' attitudes, so that schools try to make reading a culture as well as a routine activity and try to increase the number of readings in schools The benefit for the teacher is that the teacher can understand how to improve attitudes towards science, one of which is by increasing the love of reading. The benefit for the government is that with this research, it is hoped that the government can pay attention to the facilities and infrastructure to support reading activities in junior high schools so that attitudes towards science and students' abilities in the field of science can increase. The purpose of this study is to investigate and evaluate how reading preferences, attitudes toward science, and the influence of reading preferences on students' attitudes toward science in junior high school are.

\section{Methods}

The method in this research is quantitative using descriptive statistical analysis and simple linear regression analysis. Descriptive statistical analysis was conducted to find out descriptively each research variable which was carried out by surveying the research location. The survey results are interpreted to determine the general trend of the data through the mean, mode, and (Gay, Mills, \& Airasian, 2012). While the aim of the researcher to perform simple linear regression analysis is to determine the effect of the independent variable on the dependent variable. The independent variable that has been determined is the reading fondness character, while the dependent variable is the attitude towards science.

The subjects studied were students in grades 7, 8, and 9 at SMPN 19 Jambi City, SMPN 17 Jambi City, and SMP Xaverius 2 Jambi with a total sample of 411 students. The sample is determined by opinion Gay et al., (2012), namely the sampling cluster that is used as the cluster is the school. Researchers determined 3 schools out of 11 schools in Telanaipura sub-district and then determined the number of samples per school, which is a minimum of 122 students. If 3 schools are the research locations, the minimum number of samples will be 366 samples. However, in the implementation of the questionnaire, the number of samples obtained was 411 students exceeding the recommended number of standard samples.

Table 1. Research Sample

\begin{tabular}{cc}
\hline School name & Sample Frequency \\
\hline SMPN 19 Jambi City & 136 \\
SMPN 17 Jambi City & 130 \\
Xaverius 2 Junior High School Jambi & 145 \\
\hline Total sample & $\mathbf{4 1 1}$ \\
\hline
\end{tabular}


The first questionnaire is a questionnaire on the character of reading interest whose indicators were developed by researchers and have been tested for validity and reliability in different schools from where the study was conducted with a sample of 45 students. The questionnaire consists of positive and negative statements. The results of the questionnaire test obtained 33 out of 35 valid statements with a cronbach alpha of 0.912 . Furthermore, the attitude questionnaire towards science was adopted from the research Astalini \& Kurniawan, (2019), with Cronbach Alpha 0.842 taking 56 statements consisting of positive and negative statements. Both questionnaires use a Likert scale with 5 scales, including strongly agree, agree, neutral, disagree, and strongly disagree which is abbreviated as STS, TS, N, SS. For statements that are positive are worth 5 to 1 , while statements that are negative are worth 1 to 5 .

Table 2. The Number of Valid Statements and The Cronbach Alpha Value From The Questionnaire Used

\begin{tabular}{clccc}
\hline $\begin{array}{c}\text { Questionnaire } \\
\text { Variable }\end{array}$ & \multicolumn{1}{c}{ Indicator } & $\begin{array}{c}\text { Expression } \\
\text { Frequency }\end{array}$ & $\begin{array}{c}\text { Total } \\
\text { Statement }\end{array}$ & $\begin{array}{c}\text { Cronbach } \\
\text { Alpha }\end{array}$ \\
\hline Reading & Have a must-read program & 8 & 33 & 0.912 \\
Fondness & Make a library visit & 14 & & \\
Character & Buy books regularly & 11 & & \\
& Science social implications & 5 & & \\
& Scientist normality & 5 & 56 & 0.842 \\
& Attitudes towards inquiry & 9 & & \\
in IPA & Adtitude to & & \\
IPA & The fun of learning science & 10 & & \\
& Interest in increasing the & 8 & & \\
& time to study science & & & \\
& Interest in a career in & & & \\
& science & 10 & & \\
\hline
\end{tabular}

In data collection, the main objective is the data source. Data sources are divided into 2 , namely primary data and secondary data. The difference between the two is that primary data is data taken by the first source, while secondary data is taken from the first source(Martins, Cunha, \& Serra, 2018). It means that primary data are direct researchers who go into the field to collect the data. This is in line with what the researcher did, namely directly taking data in the field without taking data from other sources. Researchers collected data using google forms due to the Covid-19 outbreak, which did not allow face-to-face data collection with students. The data that has been collected is then processed using SPSS 20 software.

\section{Results and Discussion}

The results of this study were explained by descriptive statistics and linear regression to measure the effect of the independent variable on the dependent. First, the researcher explains the results obtained in descriptive statistics so that it can be seen how the condition of the reading fondness character and the attitudes of students in junior high school. 
Table 3. Descriptive Statistical Results of Reading Fondness Character

\begin{tabular}{|c|c|c|c|c|c|c|c|}
\hline Interval & Category & Frequency & $\%$ & Mean & Median & Mode & SD \\
\hline $33-59.4$ & Strongly Disagree & 1 & 0.2 & \multirow{6}{*}{111.8} & \multirow{6}{*}{109} & \multirow{6}{*}{99} & \multirow{6}{*}{17.35717} \\
\hline $59.5-85.8$ & Disagree & 13 & 3.2 & & & & \\
\hline $85.9-112.2$ & Neutral & 220 & 53.5 & & & & \\
\hline $\begin{array}{l}112.3- \\
138.6\end{array}$ & Agree & 141 & 34.3 & & & & \\
\hline $138.7-165$ & Strongly agree & 36 & 8.8 & & & & \\
\hline Total & & 411 & 100 & & & & \\
\hline
\end{tabular}

Based on Table 3, it can be seen that the percentage of $34.3 \%$ of 411 students chose to agree. Although the largest percentage is neutral, namely $53.5 \%$, the neutral category is more in the agree category than disagree. Apart from percentages, other things can be seen, namely the average of 111.8, median of 109, mode of 99, and standard deviation of 17,35717 which are also more in the agree category than the midpoint of the interval. Then it can be seen that the students of science subjects in junior high school have the character of liking to read quite well.

Table 4. Results of Attitude Descriptive Statistics

\begin{tabular}{llllllll}
\hline Interval & Category & Frequency & \% & Mean & Median & Mode & SD \\
\hline $56-100.8$ & Strongly Disagree & 0 & 0 & & & & \\
$100.9-145.6$ & Disagree & 8 & 1.9 & & & & \\
$145.7-190.4$ & Neutral & 178 & 43.3 & 196.03 & 194 & 179 & 27.05178 \\
$190.5-235.2$ & Agree & 190 & 46.2 & & & & \\
$235.3-280$ & Strongly agree & 35 & 8.5 & & & & \\
\cline { 1 - 5 } Total & & $\mathbf{4 1 1}$ & $\mathbf{1 0 0}$ & & & & \\
\hline
\end{tabular}

Based on table 4, it can be seen that the percentage of $46.2 \%$ of 411 students chose to agree. Apart from percentages, other things can be seen from the average, which is 196.03, the median is 194 , the mode is 179 , and the standard deviation is 27,05178 . So, it can be seen that students of science subjects in junior high schools have positive attitudes towards science subjects. After getting the results statistically descriptive, the researcher proceeded to the results of the simple linear regression analysis described in Tables 5 and 6.

Table 5. Model Summary

\begin{tabular}{ccccc}
\hline Model & R & R Square & Adjusted R Square & $\begin{array}{c}\text { Std. Error of the } \\
\text { Estimate }\end{array}$ \\
\hline 1 & 0.567 & 0.321 & 0.32 & 22.315 \\
\hline
\end{tabular}

Based on table 5, it can be explained from the table that the $\mathrm{R}$ value is 0.567 , the $\mathrm{R}$ Square value is 0.321 , the adjusted $\mathrm{R}$ Square value is 0.32 , and the $\mathrm{R}$ Square value is 0.32 . Std. The error of the Estimate is 22,315. It can be seen that the R Square value represents the percentage of the influence of the reading fondness on attitudes, which is $32.1 \%$. Based on table 6, it can be explained that the Unstandardized Coefficient, the value of B is 0.883 , and the standard error is 0.063 . Furthermore, in the Standardized Coefficient, the Beta value is 0.567. Then it is known that the $\mathrm{t}$ value is 13,913 and $\mathrm{p}$ is $0<0.01$, therefore it can be seen that there is a dominant influence of the reading fondness on students' attitudes towards science. 
Table 6. Coefficient

\begin{tabular}{ccccccc}
\hline \multirow{2}{*}{ Model } & \multicolumn{2}{c}{$\begin{array}{c}\text { Unstandardized } \\
\text { Coefficients }\end{array}$} & \multicolumn{2}{c}{$\begin{array}{c}\text { Standardized } \\
\text { Coefficients }\end{array}$} & t & p \\
\cline { 2 - 5 } & $\mathbf{B}$ & Std. Error & Beta & & \\
\hline \multirow{2}{*}{1} & 97.230 & 7.187 & & 13,529 & 0 \\
\cline { 2 - 5 } & $\begin{array}{c}\text { (Constant) } \\
\text { Reading Fondness } \\
\text { Character }\end{array}$ & 0.883 & 0.063 & 0.567 & 13,913 & 0 \\
\hline
\end{tabular}

\section{Discussion}

Characters of students who like to read are generally built to improve cognitive abilities. Without realizing it, the love of reading also indirectly increases students' attitudes towards a subject. The more students like to read, the more students can understand science material well and automatically students like science subjects. The cause of students not liking science subjects because according to students science subjects are difficult (Kurniawan, Astalini, \& Kurniawan, 2019; Mulyantini, Suranata, \& Margunayasa, 2019; Sujana, Dharsana, \& Jayanta, 2018). The difficulties of these students can be alleviated if students apply the character of liking to read well, so that students have a positive attitude towards science. The results of this study indicate that there is a positive influence of the character of liking to read on student attitudes in science subjects with a percentage of $32.1 \%$ in junior high school. Based on these results, by liking reading, students can think more critically and be able to analyze problems that occur while studying (Le et al., 2019; Shuraini et al., 2019). The positive influence obtained cannot be separated from the statistical results of liking to read and attitudes towards science. Positive causes can be identified from the results of a good reading interest with neutral answers leading to agree answers, and attitudes towards science with agree answers. Based on previous research, science books are more in demand by students who have higher academic achievements (Khasana, Parmiti, \& Sudatha, 2018; Kimianti \& Prasetyo, 2019; Le et al., 2019). Based on gender, the preference for reading books is more favored by female students (Aydın \& Bağc1 Ayranc1, 2018).

Research shows that students prefer to read books provided by schools, reading sources sourced from the internet, and students are interested in reading them with pleasure (Baba \& Rostam Affendi, 2020; Ho \& Ismawan Prasetia Devi, 2020). Furthermore, it is seen from the positive effect of reading pleasure on ability, love of reading has a positive effect on students' ability(Balan, Katenga, \& Simon, 2019; Le et al., 2019). Positive attitude towards reading does not mean that the number of readings is always increasing, but academic learning outcomes also increase with the pleasure of reading (Jang \& Henretty, 2019; Pertiwi, Sumarno, \& Dwi, 2019). The study results on attitudes towards reading stated that transitional students in grades 5 and 6 had more positive attitudes towards homework than students in grades 7 and 8 (Nootens et al., 2019).

Based on the statistical results of attitudes towards science, it was found that the attitude variable was in the Neutral category, which means students have an attitude that is not sure about science. The causes of doubt or uncertainty can be seen from the indicators of attitude towards science, including social implications of science, normality of scientists, attitudes towards investigations in science, adoption of scientific attitudes, pleasure in learning science, interest in increasing science learning time, and interest in a career in science that all indicators are on a neutral scale. A positive attitude towards science should be the main goal of holding science subjects. Understanding the meaning of scientific concepts of science is the purpose of holding science education, but it must begin with the desire or motivation of students to make connections to scientific concepts (Lai, Chen, \& Lee, 2019; 
Maison, Syahrial, Syamsurizal, \& Tanti, 2019). A positive attitude towards science is shown through strong continuous motivation and concrete actions. Motivation based on a sincere desire to spend time studying science and willing to participate in all activities related to the future of science (Astalini, Kurniawan, Darmaji, Sholihah, \& Perdana, 2019; Bal-Taştan et al., 2018). This study does not distinguish between male and female sex reading preferences and their effect on students' attitudes. Gender has a significant influence on student attitudes (Aini et al., 2019; Suryadi, Mirnawati, \& Fadhilah, 2020). This research implies that students' reading habit has a positive influence on science. The importance of progress in science, especially for prospective scientists who develop science and technology to facilitate people's lives. If someone wants to have a career as a scientist, then it is essential to instill a reading habit in him so that his knowledge will increase.

\section{Conclusion}

The findings in this study indicate that the character of students' love of reading is good enough so that it affects students' attitudes which are also positive towards science. Therefore, students who have compulsory reading programs, make library visits, and buy books on a regular basis will support the improvement of attitudes towards a positive direction in accordance with the attitude indicators that have been described. Having a good reading character and a positive attitude is certainly very beneficial for students and society.

\section{References}

Agathi Dian, I. A. A., Kristiantari, R. M. G., \& Ganing, N. (2015). Guru Terhadap Hasil Belajar Pengetahuan Bahasa Indonesia ( Keterampilan Membaca ) Tema Cita-Citaku Pada Siswa Kelas IV SD Desa Peguyangan. Mimbar PGSD Undiksha, 3(1). https://doi.org/http://dx.doi.org/10.23887/jjpgsd.v3i1.5172.

Aini, R. Q., Rachmatullah, A., \& Ha, M. (2019). Indonesian primary school and middle school students' attitudes toward science: Focus on gender and academic level. Journal of Baltic Science Education, 18(5), 654-667. https://doi.org/10.33225/jbse/19.18.654.

Anjani, S., Dantes, N., \& Artawan, G. (2019). Pengaruh Implementasi Gerakan Literasi Sekolah Terhadap Minat Baca Dan Kemampuan Membaca Pemahaman Siswa Kelas V SD Gugus II Kuta Utara. PENDASI: Jurnal Pendidikan Dasar Indonesia, 3(2), 74 83. https://doi.org/https://doi.org/10.23887/jpdi.v3i2.2869.

Asghar, A., Jamil, I., Iqbal, A., \& Yasmin, M. (2018). Learner Attitude towards EFL Learning: A Response from Art and Design. Open Journal of Social Sciences, 06(05), 81-88. https://doi.org/10.4236/jss.2018.65007.

Asna, \& Mimi. (2016). Peningkatan Hasil dan Kemampuan Membaca Intensif Siswa Kelas IV pada Pembelajaran Bahasa Indonesia dengan Model Pembelajaran Word Square di SD Negeri 27 Batang Anai. Jurnal Konseling Dan Pendidikan, 4(2), 74 - 78. https://doi.org/https://doi.org/10.29210/166\%y.

Astalini, A., \& Kurniawan, D. A. (2019). Pengembangan Instrumen Sikap Siswa Sekolah Menengah Pertama Terhadap Mata Pelajaran IPA. Jurnal Pendidikan Sains (Jps), 7(1), 1-7. https://doi.org/10.26714/jps.7.1.2019.1-7.

Astalini, Kurniawan, D. A., Darmaji, Sholihah, L. R., \& Perdana, R. (2019). Characteristics of students' attitude to Physics in Muaro Jambi High School. Humanities and Social Sciences Reviews, 7(2), 91-99. https://doi.org/10.18510/hssr.2019.7210.

Astuti, \& Istiarini. (2020). Upaya Meningkatkan Kemampuan Membaca Permulaan Anak Usia 5-6 Tahun Melalui Media Puzzle di PAUD Flamboyan Sukasari Kota Tangerang. Ceria: Jurnal Program Studi Pendidikan Anak Usia Dini, 8(2). 
https://doi.org/http://dx.doi.org/10.31000/ceria.v11i2.2338.

Aydın, G., \& Bağcı Ayrancı, B. (2018). Reading Preferences of Middle School Students. World Journal of Education, 8(2), 127. https://doi.org/10.5430/wje.v8n2p127.

Baba, J., \& Rostam Affendi, F. (2020). Reading Habit and Students' Attitudes Towards Reading: A Study of Students in the Faculty of Education UiTM Puncak Alam. Asian $\begin{array}{llll}\text { Journal of University } & 109 .\end{array}$ https://doi.org/10.24191/ajue.v16i1.8988.

Bal-Taştan, S., Davoudi, S. M. M., Masalimova, A. R., Bersanov, A. S., Kurbanov, R. A., Boiarchuk, A. V, \& Pavlushin, A. A. (2018). The Impacts of Teacher's Efficacy and Motivation on Student's Academic Achievement in Science Education among Secondary and High School Students. EURASIA Journal of Mathematics, Science and Technology Education, 14(6), 2353-2366. https://doi.org/10.29333/ejmste/89579.

Balan, S., Katenga, J. E., \& Simon, A. (2019). "Reading Habits and their Influence on Academic Achievement among Students at Asia Pacific International University, Thailand." Abstract Proceedings International Scholars Conference, 7(1), 14691495. https://doi.org/10.35974/isc.v7i1.928.

Christianti, M. (2013). Membaca dan Menulis Permulaan Untuk Anak Usia Dini. Jurnal Pendidikan Anak, 2(2). https://doi.org/https://doi.org/10.21831/jpa.v2i2.3042.

Darmayasa, I. K., Jampel, N., \& Simamora, A. H. (2018). Pengembangan E-Modul Ipa Berorientasi Pendidikan Karakter Di Smp Negeri 1 Singaraja. Jurnal Edutech Undiksha, 6(1), 53-65. https://doi.org/http://dx.doi.org/10.23887/jeu.v6i1.20267.

DiMaggio, P., Sotoudeh, R., Goldberg, A., \& Shepherd, H. (2018). Culture out of attitudes: Relationality, population heterogeneity and attitudes toward science and religion in the U.S. Poetics, 68(October), 31-51. https://doi.org/10.1016/j.poetic.2017.11.001.

Faruq, A. Z. Al. (2019). Reading anxiety in English as a foreign language for undergraduate students in Indonesia. Journal of Teaching and Learning English in Multicultural Contexts (TLEMC), 3(2), 88-95.

Gay, L. R., Mills, G. E., \& Airasian, P. W. (2012). Educational Research Competencies for Analysis and Applications (10th ed.). Pearson Education, Inc.

Genc, M., Genc, T., \& Rasgele, P. G. (2018). Effects of nature-based environmental education on the attitudes of 7 th grade students towards the environment and living organisms and affective tendency. International Research in Geographical and Environmental Education, 27(4), 326-340. https://doi.org/10.1080/10382046.2017.1382211.

Hewi, L., \& Shaleh, M. (2020). Refleksi Hasil PISA (The Programme For International Student Assesment): Upaya Perbaikan Bertumpu Pada Pendidikan Anak Usia Dini). Jurnal Golden Age, 4(1). Retrieved from https://ejournal.hamzanwadi.ac.id/index.php/jga/article/view/2018.

Ho, L., \& Ismawan Prasetia Devi. (2020). A New trend in understanding students' interest in learning science: microetnography. Integrated Science Education Journal (ISEJ), 1(2), 62-66. https://doi.org/10.37251/isej.v1i2.72.

Hochweber, J., \& Vieluf, S. (2018). Gender differences in reading achievement and enjoyment of reading: The role of perceived teaching quality. Journal of Educational Research, 111(3), 268-283. https://doi.org/10.1080/00220671.2016.1253536.

Ika Febriandari, E. (2019). Penanaman Nilai Karakter Gemar Membaca Berbasis Pembiasaan Dan Keteladanan Terhadap Kemampuan Berbahasa Siswa Sekolah Dasar. Journal AL-MUDARRIS, 2(2), 211. https://doi.org/10.32478/al-mudarris.v2i2.286.

Jang, B. G., \& Henretty, D. (2019). Understanding multiple profiles of reading attitudes among adolescents. Middle School Journal, 50(3), 26-35. https://doi.org/10.1080/00940771.2019.1603803. 
Khasana, I. N., Parmiti, D. P., \& Sudatha, I. G. W. (2018). Pengembangan Media Monopoli Dengan Model Hannafin Dan Peck Mata Pelajaran Ips Di Sd Mutiara Singaraja. Jurnal Jurusan Teknologi Pendidikan, 6(2), 205-214. https://doi.org/http://dx.doi.org/10.23887/jeu.v6i2.20292.

Kimianti, \& Prasetyo. (2019). Pengembangan E-Modul IPA Berbasis Problem Based Learning Untuk Meningkatkan Literasi Sains Siswa. Kwangsan Jurnal Teknologi Pendidikan, 7(2). https://doi.org/https://doi.org/10.31800/jtp.kw.v7n2.p91--103.

Kurniawan, D. A., Astalini, A., \& Kurniawan, N. (2019). Analisis Sikap Siswa Smp Terhadap Mata Pelajaran Ipa. Lentera Pendidikan: Jurnal Ilmu Tarbiyah Dan Keguruan, 22(2), 323. https://doi.org/10.24252/lp.2019v22n2i14.

Lai, A. F., Chen, C. H., \& Lee, G. Y. (2019). An augmented reality-based learning approach to enhancing students' science reading performances from the perspective of the cognitive load theory. British Journal of Educational Technology, 50(1), 232-247. https://doi.org/10.1111/bjet.12716.

Le, T. T. H., Tran, T., Trinh, T. P. T., Nguyen, C. T., Nguyen, T. P. T., Vuong, T. T., ... Vuong, Q. H. (2019). Reading habits, socioeconomic conditions, occupational aspiration and academic achievement in Vietnamese junior high school students. Sustainability (Switzerland), 11(18), 1-29. https://doi.org/10.3390/su11185113.

Lee, S., \& Kim, S. H. (2018). Scientific Knowledge and Attitudes Toward Science in South Korea: Does Knowledge Lead to Favorable Attitudes? Science Communication, 40(2), 147-172. https://doi.org/10.1177/1075547017753189.

Lian, B., Kristiawan, M., Ammelia, D., Primasari, G., Anggung, M., \& Prasetyo, M. (2020). Teachers' Model in Building Students' Character. Journal of Critical Reviews, 7(14), 927-932. https://doi.org/10.31838/jcr.07.14.165.

Maison, M., Haryanto, H., Ernawati, M. D. W., Ningsih, Y., Jannah, N., Puspitasari, T. O., \& Putra, D. S. (2020). Comparison of student attitudes towards natural sciences. International Journal of Evaluation and Research in Education, 9(1), 54-61. https://doi.org/10.11591/ijere.v9i1.20394.

Maison, M., Syahrial, Syamsurizal, \& Tanti. (2019). Learning Environment, Students' Beliefs, And Self-Regulation In Learning Physics: Structural Equation Modeling. Journal of Baltic Science Education, 18(3), 389-403. https://doi.org/10.33225/jbse/19.18.389.

Martins, F. S., Cunha, J. A. C. da, \& Serra, F. A. R. (2018). Secondary Data in Research Uses and Opportunities. PODIUM Sport, Leisure and Tourism Review, 7(3), I-IV. https://doi.org/10.5585/podium.v7i3.316.

Maryani, N., Ichsan, M., \& Khairunnisa. (2017). Signifikansi Metode Guide Reading Terhadap Motivasi Belajar Siswa Dalam Teori Membaca Nyaring Guide Reading Method On Students ' Learning Motivation In Reading Loudly Lesson. Didaktika Tauhidi: Jurnal Pendidikan Guru Sekolah Dasar, 4(2), 126-139. https://doi.org/http://dx.doi.org/10.30997/dt.v4i2.924.

Maufur, S., \& Puadah, A. (2015). Pengaruh Bimbingan Orang Tua Terhadap Kemampuan Membaca Siswa Kelas Rendah Di Sd Negeri Cimohong 02 Kecamatan Bulakamba Kabupaten Breb. AL IBTIDA: JURNAL PENDIDIKAN GURU MI, 6(1). https://doi.org/https://doi.org/10.24235/al.ibtida.snj.v2i1.178.

Meilani, D., Dantes, N., \& Tika, I. N. (2020). Pengaruh Implementasi Pembelajaran Saintifik Berbasis Keterampilan Belajar dan Berinovasi 4C terhadap Hasil Belajar IPA dengan Kovariabel Sikap Ilmiah pada Peserta Didik Kelas V SD Gugus 15 Kecamatan Buleleng. Jurnal Elementary: Kajian Teori Dan Hasil Penelitian Pendidikan Sekolah Dasar, 3(1), 1-5. https://doi.org/https://doi.org/10.31764/elementary.v3i1.1412.

Memiş, A. D., \& Kandemir, H. (2019). The Relationship Between the Study Habits and 
Attitudes and Metacognitive Reading Comprehension Self-Awareness, Reading Comprehension, Reading Attitudes. World Journal of Education, 9(4), 133. https://doi.org/10.5430/wje.v9n4p133.

Muhtar, T., \& Dallyono, R. (2020). Character Education From the Perspectives of Elementary School Physical Education Teachers. Jurnal Cakrawala Pendidikan, 39(2), 395-408. https://doi.org/10.21831/cp.v39i2.30647.

Mulyantini, N. L. D., Suranata, K., \& Margunayasa, I. G. (2019). Pengaruh Model Pembelajaran Two Stay Two Stray Terhadap Minat Belajar Ipa Siswa Kelas IV SD. MIMBAR PGSD Undiksha, 7(1). https://doi.org/http://dx.doi.org/10.23887/jjpgsd.v7i1.17023.

Munawwaroh, A. (2019). Keteladanan Sebagai Metode Pendidikan Karakter. Jurnal Penelitian Pendidikan Islam, 7(2), 141. https://doi.org/10.36667/jppi.v7i2.363.

Nootens, P., Morin, M. F., Alamargot, D., Gonçalves, C., Venet, M., \& Labrecque, A. M. (2019). Differences in attitudes toward reading: A survey of pupils in grades 5 to 8 . Frontiers in Psychology, 9(JAN), 1-13. https://doi.org/10.3389/fpsyg.2018.02773.

Novitasari, L., \& Wardani, N. S. (2020). Pengembangan Instrumen Sikap Toleransi Dalam Pembelajaran Tematik Kelas 5 SD. Jurnal Penelitian Tindakan Kelas Dan Pengembangan Pembelajaran, 3(1). https://doi.org/http://dx.doi.org/10.31604/ptk.v3i1.41-52.

Öztürk, M., Akkan, Y., \& Kaplan, A. (2020). Reading comprehension, Mathematics selfefficacy perception, and Mathematics attitude as correlates of students' non-routine Mathematics problem-solving skills in Turkey. International Journal of Mathematical Education in Science and Technology, 51(7), 1042-1058. https://doi.org/10.1080/0020739X.2019.1648893.

Pertiwi, I. N., Sumarno, \& Dwi, A. (2019). Pengaruh Model Make A Match Berbantu Media Kartu Bergambar terhadap Kemampuan Membaca dan Menulis. MIMBAR PGSD Undiksha, 7(3), 261-270. https://doi.org/http://dx.doi.org/10.23887/jjpgsd.v7i3.19412.

Purwanto, Y., \& Rizki, S. (2015). Pengembangan Bahan Ajar Berbasis Kontekstual Pada Materi Himpunan Berbantu Video Pembelajaran. AKSIOMA Journal of Mathematics Education, 4(1), 67-77. https://doi.org/10.24127/ajpm.v4i1.95.

Puryadi, P., Rahayu, S., \& Sutrio, S. (2018). Pengaruh Model Pembelajaran Direct Instruction Berbantuan Bahan Ajar Berbasis Kontekstual Terhadap Hasil Belajar IPA Terapan Siswa Kelas X SMKN 4 Mataram Tahun Ajaran 2015/2016. Jurnal Pendidikan Fisika Dan Teknologi, https://doi.org/https://doi.org/10.29303/jpft.v4i1.329.

Puspita, L. (2019). Pengembangan Modul Berbasis Keterampilan Proses Sains Sebagai Bahan Ajar Dalam Pembelajaran Biologi. Jurnal Inovasi Pendidikan IPA, 5(1), 7987. https://doi.org/https://doi.org/10.21831/jipi.v5i1.22530.

Rabgay, T. (2018). The effect of using cooperative learning method on tenth grade students' learning achievement and attitude towards biology. International Journal of Instruction, 11(2), 265-280. https://doi.org/10.12973/iji.2018.11218a.

Rosyad, A. M. (2019). Implementasi Pendidikan Karakter Melalui Kegiatan Pembelajaran Di Lingkungan Sekolah. Tarbawi: Jurnal Keilmuan Manajemen Pendidikan, 5(2), 173190. https://doi.org/http://dx.doi.org/10.32678/tarbawi.v5i02.2074.

Simsar, A. (2018). Early Childhood Turkish Children's Attitudes toward Science. 14(3), 113-122. https://doi.org/10.29329/ijpe.2018.146.8.

Smith, T. J., Walker, D. A., Chen, H. T., \& Hong, Z. R. (2020). Students' Sense of School Belonging and Attitude towards Science: a Cross-Cultural Examination. International Journal of Science and Mathematics Education, 18(5), 855-867. 
https://doi.org/10.1007/s10763-019-10002-7.

Sriyanto, Leksono, \& Harwanto. (2019). Bahan Ajar PPKn Berbasis Karakter dan Literasi Untuk Siswa Kelas IX SMP Al Hikmah Surabaya. Edmotech, 4(2), 130-142. https://doi.org/http://dx.doi.org/10.17977/um039v4i22019p130.

Sujana, D. M. A., Dharsana, I. K., \& Jayanta, I. N. L. (2018). Pengaruh Model Pembelajaran Kooperatif Tipe Two Stay Two Stray melalui Lesson Study terhadap Hasil Belajar IPA. MIMBAR PGSD Undiksha, 6(2). https://doi.org/http://dx.doi.org/10.23887/jjpgsd.v6i2.19462.

Suryadi, A., Mirnawati, M., \& Fadhilah, N. (2020). Perbedaan Sikap Siswa Terhadap Sains: Studi Berdasarkan Level Pendidikan Dan Gender. Jurnal Pendidikan Matematika Dan IPA, 11(2), 206. https://doi.org/10.26418/jpmipa.v11i2.36832.

Syuraini, Jamaris, \& Jalius. (2019). Building Reading Fondness Through Management Taman Bacaan Masyarakat ( TBM ). Jurnal Pendidikan Kebutuhan Khusus, 3(2), 1721.

Toma, R. B., Greca, I. M., \& Orozco Gómez, M. L. (2019). Attitudes towards science and views of nature of science among elementary school students in terms of gender, cultural background and grade level variables. Research in Science and Technological Education, 37(4), 492-515. https://doi.org/10.1080/02635143.2018.1561433.

Toma, Radu Bogdan, \& Greca, I. M. (2018). The effect of integrative STEM instruction on elementary students' attitudes toward science. Eurasia Journal of Mathematics, Science and Technology Education, 14(4), 1383-1395. https://doi.org/10.29333/ejmste/83676.

Tse, W. S., Choi, L. Y. A., \& Tang, W. S. (2019). Effects of video-based flipped class instruction on subject reading motivation. British Journal of Educational Technology, 50(1), 385-398. https://doi.org/10.1111/bjet.12569.

Vuong, Q. H., Le, A. V., La, V. P., Vuong, T. T., Do, T. H., Vuong, H. M., ... Ho, M. T. (2019). A dataset of vietnamese junior high school students' reading preferences and habits. Data, 4(49), 1-12. https://doi.org/10.3390/data4020049.

Wahyuni, N. E., Muslim, A., \& Pamujo. (2019). Pengaruh Model Discovery Learning Terhadap Sikap Peduli Lingkungan Dan Prestasi Belajar Ipa Sekolah Dasar. Jurnal Elementaria Edukasia, 2(2), 147-153. https://doi.org/http://dx.doi.org/10.31949/jee.v2i2.1493.

Wan Yunus, F., \& Mat Ali, Z. (2018). Attitude towards Learning Chemistry among Secondary School Students in Malaysia. Asian Journal of Behavioural Studies, 3(9), 63. https://doi.org/10.21834/ajbes.v3i9.61.

Warsihna, J. (2016). Meningkatkan Literasi Membaca dan Menulis dengan Teknologi Informasi dan Komunikasi. Kwangsan, 4(2), $67-80$. https://doi.org/https://doi.org/10.31800/jtp.kw.v4n2.p67--80.

Wu, W. H., Kao, H. Y., Wu, S. H., \& Wei, C. W. (2019). Development and evaluation of affective domain using student's feedback in entrepreneurial Massive Open Online Courses. Frontiers in Psychology, 10(MAY). https://doi.org/10.3389/fpsyg.2019.01109.

Yoga Purandina, I. P., \& Astra Winaya, I. M. (2020). Pendidikan Karakter di Lingkungan Keluarga Selama Pembelajaran Jarak Jauh pada Masa Pandemi COVID-19. Cetta: Jurnal Ilmu Pendidikan, 3(2), 270-290. https://doi.org/10.37329/cetta.v3i2.454. 